\title{
直列コンデンサ補償系統における同期機の 軸氼じれ共振現象とその抑制
}

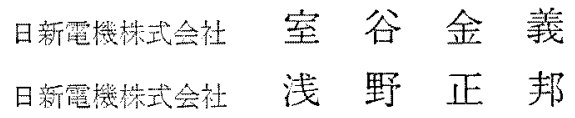

\section{1. まえがき}

蕰列コンデンサ结，超高正長距離送電線の送電容量 增大対策として広々使用されているが，声列コンデン

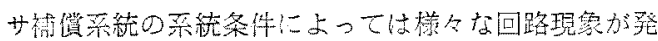
生守るので，現象の発生機满，解析手法，抑制方法に つて十分梌討し，系統の安全性を高的る必要が市る。 この直列コンデンサ榑償系統の不定定現皱の1つと して，同期譏の自己励磁現象が古り，数 10 年前より 数多くの機関で研究されているが，算者らは，発電機 の界磁電正在適当な制御系で制御することにより自己 焗磁現泉を抑制守る方法(NDS 上仮称) を考案し， 理諭的・寒娩的に三の效果を確喼し，直列コンデンサ 道用技衔老高的た代(2)。

しかしながら，最近アメリカの实系統において，軸

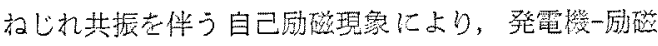
譏間のシャフトが過熟され，コレクター部が絶緑破壊 したことが報告さ机(3)，直列コンデンサ補償系続の新 なな閭題として，同期機の軸䄪じ机共振現象*につい

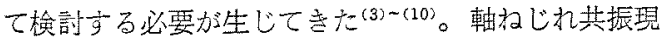
象は，直列コンデンサ合む䉓気系の固有振動周波数 が回転機の朝系の機械的共振周波数に近い場合に，面 者の相互結合作用により引起こされる現象で, 電気振

Subsynchronous Resonance Oscillations in Series-Compensated Transmission Systems, and their Suppression. By Kaneyoshi Murotani, Member \& Masakuni Asano, Member (Electrical Power Sys., Lad., R \& Dept., Nissin Electric Co., Ltd.)

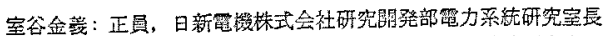

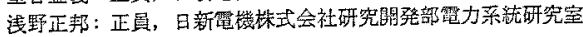

*: アメリカで估 Self-Excited Torsional Frequency Oscillation と称した喰文(4)もあるが、最近は，简單に Subsynchronous

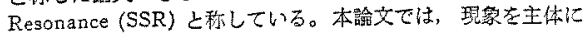
して㷁礼しれ共振愣家と琵現することにする。

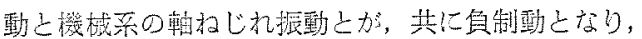

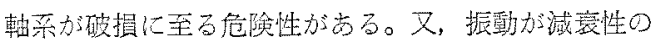
場合でむ，系統事故・直列コンデンサこう入などの一 畤的な䒺統じょう乱により，軸初じれ振動が長時間持

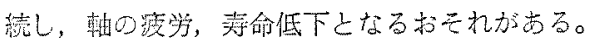

本諭文佶，乙の軸的じれ共振現象が発䨮機の入出力 トルクの差に起因していることに着目し，タービン， 発電機の入力トルク, 又は, 出力トルク(䨞気的出力)

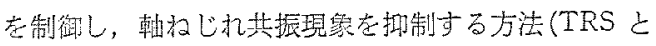
仮称) を提案するものであり，ディジタル計算機，ア ナログ計算機を使用した理論解析により，その效果を 確認した結累を報告し，更に，これの具体化について の数例の具体案屯提案している。

2. 同期機の自己励磁現象亡界磁制御による 抑制(1)(2)

雪力系統の同期機の安定問題には，

（1）定態安定度，又は，動態安定度老詨象とした 安定間題

（2）同期機の乱調による安定問題

（3）同期機の自己励磁現象に上る安定問題

（4）軸ねじれ振動に基づく安定問題

が台り，通常，(2)〜(4)を負制動現象之称するが， (1)を含好ている論文(11) むある。

直列コンデンサの補償度を上げることによって， （1）の安定度は向上するが，逆に，(2)，(3) は不安 定に向う傾向があり，直列コンデンサ禣償度の上限を 決定する要因となる。(4)は本稿の主題であり, 第 3 章住詳述する。

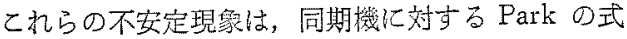
と外部回路の式とを連立主ることにより，統一的に取 

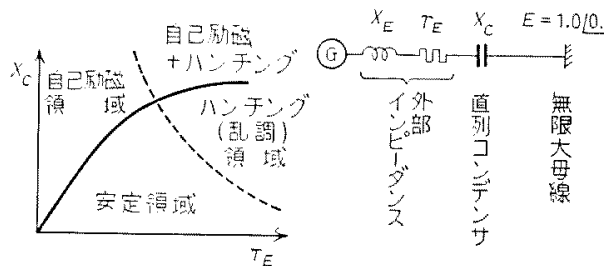

第 1 田制動現象発生領域

Fig. 1. Stability borderlines for negative damping oscillations.

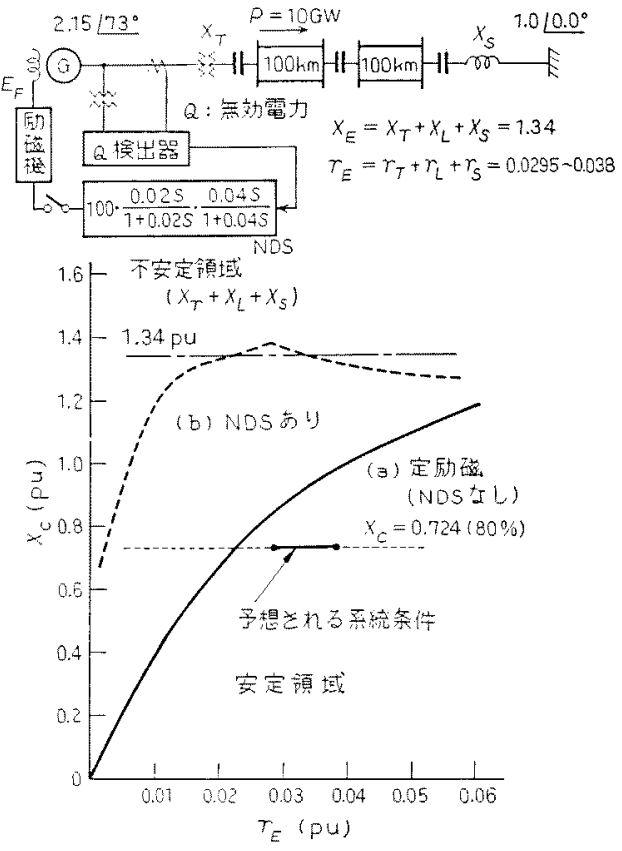

簀 2 国 $500 \mathrm{kV}$ モデル采統に拈ける自己励 磁現䪿発生領域上 NDS 亿よる効果

Fig. 2. Stability borderlines for self-excited oscillations in model $500 \mathrm{kV}$ system with and without NDS.

报うことができ，アナログ計算機やデイジタル計算機

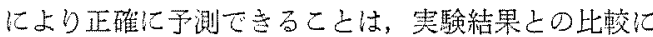
和いて㭘証されている。

(2)，（3）の発生領域は一般に，第 1 图に示すよう であり，(2)经回路抵杭が大きい程発生しやすく，逆 に(3)は回路抵抗の小さい方が発生しやすい。

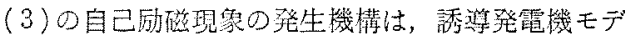
ルで颜明するこしがでる。この現象が発生すると，

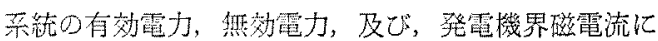
低周波の振動加現放れる。これらの变動要素を蚞出し て，界磁電生艺制湖するととか，目己励磁現象抑制装 置(NDS; Negative Damping Stabilizer) の考光方で
ある。第 2 図, $500 \mathrm{kV}$ モデル系統での安定判別曲線 計镜結果を示す。NDS をえう入すると，破線で示す ように安定領域加斑大さ机ている。

\section{3. 軸的じれ共振現象}

〈3.1〉計算モデル系統と発生機構第3图に朝 权じ扎現象を考察するための等俩回路を示す。記号の

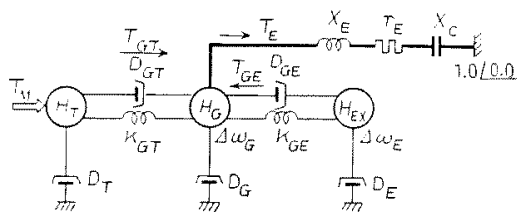

第 3 図 軸采を含むモデル采統

Fig. 3. The model system for analyzing the subsynchronous resonance oscillations (SSR).

第 1 表 計算定数上記号の説明

Table 1. Symbols and data.

\begin{tabular}{|c|c|c|c|c|c|}
\hline & 記号 & 配号内容 & 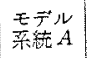 & $\begin{array}{l}€ \overline{7} ル \\
\text { 采統B }\end{array}$ & $\begin{array}{l}\text { Hydro } \\
\text { System (4) }\end{array}$ \\
\hline \multirow[b]{3}{*}{ 蟣 } & $H_{T}$ & 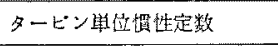 & 2.22 & 0.667 & 2. 4825 \\
\hline & $H_{G}$ & 発雪梿 & 0.633 & 1.333 & 4. 1375 \\
\hline & $H_{E}$ & 湖磁隐 & - & 0.0667 & - \\
\hline \multirow[t]{2}{*}{ 梒 } & $K_{G T}$ & 軸の壮初定数 & 25 & 25 & 22.5 \\
\hline & $K_{G E}$ & " & - & 9 & - \\
\hline 菜 & $D_{T}$ & 轿棫的制動寀数 & 0.5 & 0.5 & 1.0 \\
\hline 定 & $D_{G}$ & " & 0.5 & 2.0 & 0.0 \\
\hline \multirow{3}{*}{ 数 } & $D_{E}$ & $"$ & - & 0.0 & - \\
\hline & $D_{G T}$ & $"$ & 0.6 & 0.6 & 0.6 \\
\hline & $D_{G E}$ & " & - & 0.25 & - \\
\hline \multirow{10}{*}{ 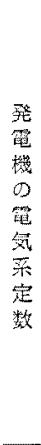 } & $r_{a}$ & 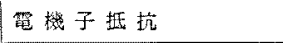 & 0.0015 & \multirow{10}{*}{ 同 } & 0.005 \\
\hline & $x_{1}$ & 電機子漏水少アクタンス & 0.20 & & 0.153 \\
\hline & $x_{d}$ & 茴朝同期りアクタンス & 1.50 & & 1.0 \\
\hline & $X_{q}$ & 瀵轴 & 1.49 & & 0.66 \\
\hline & $X_{d^{\prime}}$ & 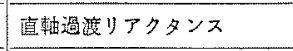 & 0.31 & & 0.346 \\
\hline & $T_{d o^{\prime}}$ & "關路時定数 & 7.2 & & 7.42 \\
\hline & $X_{d}^{\prime \prime}$ & "次過溲リア゙クタンス & 0.25 & & 0.2405 \\
\hline & $T_{d o^{\prime \prime}}$ & " 開路初期時定数 & 0.043 & & 0.0347 \\
\hline & $X_{Q}{ }^{\prime \prime}$ & 横軸次滇湾リアクタンス & 0.25 & & 0.3249 \\
\hline & $T_{80}{ }^{\prime \prime}$ & “周路初绐時定数 & 0.21 & & 0.0598 \\
\hline \multirow{6}{*}{ 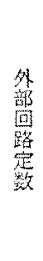 } & $r E$ & $r_{a}$ 者含む全外部回路の抵抗 & 变数 & \multirow{6}{*}{ 同 } & 变数 \\
\hline & $X_{T}$ & 变正器瀑扟りアクタンス & 0.135 & & 0.0 \\
\hline & $X_{L}$ & 線 路 & 0.905 & & 1.1224 \\
\hline & $x_{S}$ & 背啐菜皖 & 0.30 & & 0.0 \\
\hline & $x_{E}$ & $=\left(X_{T}+X_{L}+X_{S}\right)$ & 1.34 & & 1.1224 \\
\hline & $X c$ & 遖列コンデンサ & 湾数 & & 窝数 \\
\hline
\end{tabular}


内容と計算に使用した定数学第 1 表にまとめて示す。 電気系の定数は第 2 図之同じ(1)であるが，機械系の定 数は遁当に仮定したものである。

図示されたように，タービン・発電機・励磁機は， 䩜の私じれ方向について力学的に見た場合, 慣性体

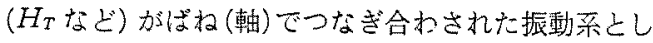
て表路される。従って，各慣性体間には，ば构と慣性 定数化上り，機棫的共振現像の発生す石周波数加存在 しこの值 $f_{M}$ は第 3 园で $H_{G} \cdot H_{T}$ 間のみを考元た場 合次式で与えられる。

$$
f_{M}=\sqrt{\frac{K_{G T}}{4 \pi f_{0} H_{G} H_{T} /\left(H_{G}+H_{T}\right)}} f_{0} \ldots
$$

一般に，この周波数住系統の基本周波数 $\left(f_{0}\right)$ 上り低 い值で市る。

系統に直列コンデンサをそう入放る，次式で表わ される $f_{n}$ の振勳が発生する。

$$
f_{n}=\sqrt{X_{C} /\left(X_{E}+X_{2}\right)} f_{0} \ldots
$$

但し, $X_{E}$ : 発電機以外のリアクタンス,

$X_{2}$ : 発電機の逆相りアクタンス

電被子に $f_{n}$ の電流が流机る之, 界磁巻總にすの゙り周 波数 $\left(f_{E}=f_{0}-f_{n}\right)$ の電流加誘起され，回転子に $f_{E}$ で眽動するトルクが発生する。

$f_{E} \fallingdotseq f_{M}$ の埸合, このトルク振動に上り, 軸系の振

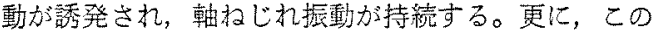
$f_{E}$ の軸放じれ振動は，電気系に $\left(f_{n}=f_{0}-f_{E}\right)$ の周 波数の電流を誘起するので， $f_{n}$ の振動はますます大 きくなる(4)。

この上うに，電気菜上機械采の結合加強い場合に は, 雪気系の振動，機械系の軸格じれ振動が共に発散 性となり，電気系では直列コンデンサに過電圧が印加 され，機械系では軸疲学となり，これる軸ねじれ共振 現家と称している。

〈3.2〉解析手法 朝极じれ共振現象の理論的解 析には，他の研究者上同様，系を峰少变動仁対する特 性方程式で表わし，ディジタル計算機でその特性根老 求好る方法を採用した。Concordia 氏らが，文献 (4) で,Hydro System の軸权じれ共振現象の発生领域老 紹们してるが，篗者らもこの系統について安定判別 計算を厅ない，第 4 図の結果を得た。発電機出力およ び機珹系の単位が不明であることすあって，両者の発 生領域化幾分差があるが，解析手法の妥当性は，確認 できたものと考元ている（定数は第1表に示す）。

この特性根による安定判別法は, 軸称じれ共振現象 の発生限界を理論的に求めるには便利であるか，䒺統 じょう乱により発生する過渡振動トルクの大きさなど

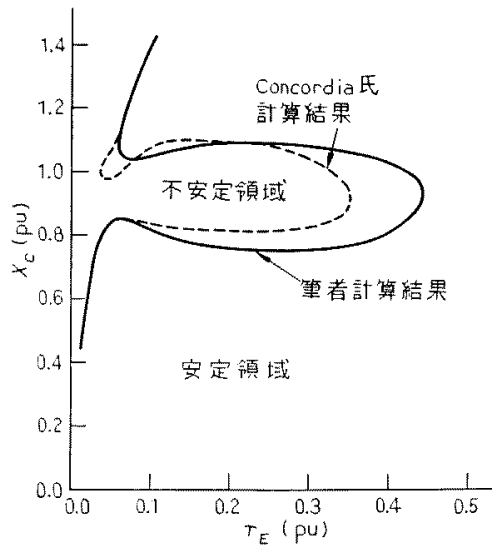

第 4 圆 Hydro system の軸就じれ共振 現象発生領域

Fig. 4. Stability borderlines for SSR in hydro system.

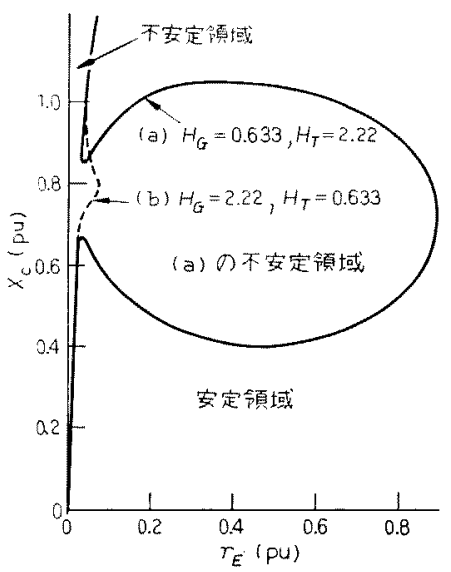

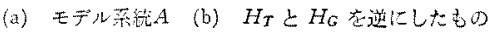

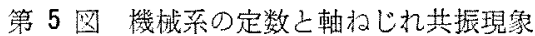
発生領域 (10GVA ベース)

Fig. 5. Stability borderlines for SSR in the model system with two inertia constants.

の計算には不適当であるので，系全体を示す非線形連 立微分方程式をアナログ計算機でシミュレーションす る解析法季併用した。

〈3.3〉 モデル系統における軸构じれ共振現象発生 領域 モデル采統 $A$ の軸称じ机共振現象発生領域を 第 5 図 (a)に, タービンと発電機の惯性定数を逆にし たケースの発生領域を(b)に示す。而図の比較加ら明 らかなように，電気系とつながる $H_{G}$ が小さく，振動 子となる $H_{T}$ の大きい方が安定領域が広くなることが 判る。

モデル系統 $B$ の軸ねじれ共振現象発生領域を第 6 図 


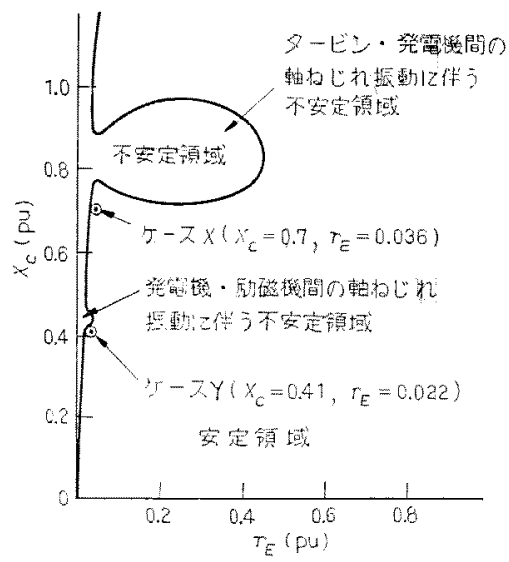

第 6 図 モデル系統Bにおける軸的じれ 共振現象の発生領域 (10GVA ベース)

Fig. 6. Stability borderlines for SSR in the model system with three inertia con. stants.

に示す。惯性体がつつおるため， $H_{T}, H_{G}$ 間の共振も ードと， $H_{G}, H_{E}$ 間の共振モードがあり, 各々, $X_{C}$ が $0.8 \mathrm{pu}, 0.4 \mathrm{pu}$ の近傍て発生している。

$H_{T}, H_{G}$ 間の振敦では $H_{G}<H_{T}$ であるから不安定 領域が大きく, $H_{G}, H_{E}$ 間の振動では $H_{G}>H_{E}$ であ る加ら不安定領域は小さい。乙机は第 5 図(a)，(b) の関你と同じ傾向を示している。

\section{4. 軸ねじれ共振現象の抑制}

〈4・1〉考え方 節笚のため第 7 図に示すように 慣性体がタービンと発電機の2つである゙ケースについ て考察する。

一般にタービン発電機の機械系の方程式は，次の式 で表わされる。

$$
\begin{aligned}
2 H_{T} P \Delta \omega_{T}= & T_{M}-T_{G T}-D_{T} \Delta \omega_{T} \\
& +D_{G T} \Delta \omega_{G T} \ldots \ldots \ldots \\
2 H_{G} P \Delta \omega_{G}= & T_{G T}-T_{E}-D_{G} \Delta \omega_{G} \\
& -D_{G T} \Delta \omega_{G T} \ldots \ldots \ldots
\end{aligned}
$$

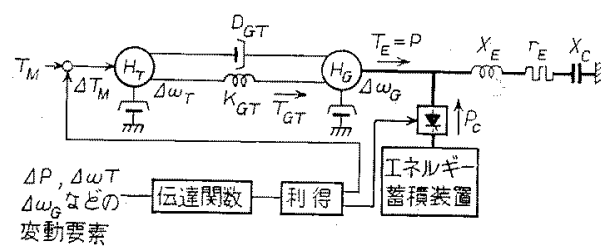

第 7 困軸礼じれ共振現象抑制方式 (TRS) の原理図

Fig. 7. Principle diagram of TRS (Tortional Resonance Stabilizer).

$$
\begin{aligned}
& P \delta_{G}=\Delta \omega_{G} \\
& P \delta_{T}=\Delta \omega_{T}
\end{aligned}
$$

但し,

$$
\begin{aligned}
& T_{G T}=K_{G T}\left(\delta_{G}-\delta_{T}\right) \\
& \Delta \omega_{G T}=\Delta \omega_{G}-\Delta \omega_{T}
\end{aligned}
$$

軸ねじれ共振現象は，第 10 図(a)に示すように軸 トルク $T_{G T}$ が機械系の共振周波数で大きく振動する 現象であるが，機械的入力 $T_{M}$ は一定であるので, 電気的出力 $T_{E}$ の変動飞起因しているととが, 同図及 び上記方程式より明らかである。

ここでは，軸ねじれ共振現象を㧕制する手段として 次のあのを考えてみる。

（i） $T_{E}$ の変化に対応して，タービンの蒸気入力 $T_{M}$ を制御する(第 7 図参照)。

(ii） $T_{E}$ が一定となるように電気系に接続した土 ネルギー蓄積洨置 $(\mathrm{Pc})$ を制御する(第7 图参照)。

（iii）界磁制御により，系統じょう乱時の過渡振動 を速や加減哀させる。

この内，(i)，(ii）は有効電力に関係する要素を直 接制御しようとするものであり，以下てれらを TRS (Torsional Resonance Stabilizer) 乙仮称することにす る。又，（面)は前述の NDS で界磁制御を行なって電 気采の振動制御を行なっていることから，TRS 之対 象的に無効電力制御と考えることができよう。以下を 制御する方式について少し詳しい理諭検討を行なう。

\section{$\langle 4 \cdot 2\rangle$ TRS の理論検討 TRS の入力信号や，}

伝達関数としては，種々のむのが考兄られる。この中 より最適な制御系を選定することが必要であり，とれ を次の上うな方法で求めた。

第 2 表は，入力信号の種別として $\Delta P$ など 4 種，伝 達関数として 6 種類を選定して, 安定判別計算を行な ったすのである。第 3 表は，入力信号として $\Delta \omega_{G}$ を 使用したときの，固有值の動きを示すむのである。系 統条件は，モデル系統 $A$ であり， $X_{\mathrm{c}}=0.81 \mathrm{pu}, R_{E}=$ $0.045 \mathrm{pu}$ とした。固有値の虚数部は，振動の周波数を 示し，実数部はその周波数の振動の減衰・增加を示す 時定数に関係するすので，乙れが正になる之增加，即 ち，発散性であるととを示す。

これより次のことが言える。

（1）入力信号源としては， $\Delta Q$ は不道当であり， $\Delta P, \Delta \omega_{G}, \Delta \omega_{T}$ が適当である。

（2）伝達関数は微分回路が望ましい。

以上より，伝達関数の形を選定したが，次に，利得 の大きさを選定するため, 次式のような 2 階微分回路 形 $\left(P^{2}\right)$ とし， $K$ TRS と固有值の関係を求めた。 


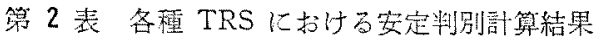

Table 2. Suppression of subsynchronous resonance with various kinds of TRS.

\begin{tabular}{|c|c|c|c|c|c|}
\hline 入Ji管号 & $-J P$ & $+\Delta \omega_{C}$ & $-\Delta \omega_{T}$ & $-\Delta Q$ & 描 \\
\hline な & $x$ & $x$ & $x$ & $x$ & 定䟥磁 \\
\hline NDS & $x$ & $x$ & $x$ & $x$ & +2 \\
\hline$P^{*}+\mathrm{NDS}$ & $x$ & 0 & 0 & $x$ & $\begin{array}{r}50 \times(0.04 S / 1+0.04 S) \\
\times(0.02 S / 1+0.02 S) \\
\times(0.06 S / 1+0.06 S)\end{array}$ \\
\hline$P *+\mathrm{NDS}$ & 0 & 0 & 0 & $x$ & $\begin{array}{r}50 \times(0.04 S / 1+0.04 S) \\
\times(0.02 S / 1+0.02 S)\end{array}$ \\
\hline$P+\mathrm{NDS}$ & 0 & 0 & 0 & $x$ & $50 \times(0.04 S / 1+0.04 S)$ \\
\hline$D+\mathrm{NDS}$ & $x$ & $x$ & $x$ & $x$ & 20 \\
\hline$I+\operatorname{NDS}$ & $x$ & $x$ & $x$ & $x$ & $\begin{array}{c}50 \times(1+0.001 S / \\
S+0.01)\end{array}$ \\
\hline$I^{2}+N D S$ & $x$ & $x$ & $x$ & $x$ & $50 \times(1+0.001 S /$ \\
\hline
\end{tabular}

(1) Oは安定, x住不安定京京。

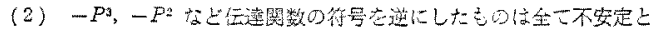
5。

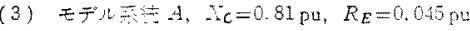

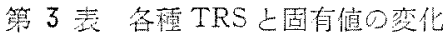

Table 3. The changing of each eigenvalue with various kinds of TRS.

\begin{tabular}{|c|c|c|c|c|c|}
\hline \multirow{2}{*}{ 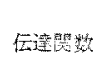 } & \multicolumn{5}{|c|}{ 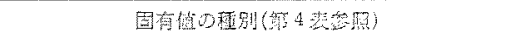 } \\
\hline & $\mathrm{ND}$ & $\mathrm{TR}$ & CNDS & CTRS & $\mathrm{HT}$ \\
\hline 衫 & $\begin{array}{l}-0.985 \\
\pm 20.25\end{array}$ & $\begin{array}{l}+0.015^{*} \\
\pm j 0.29\end{array}$ & & $\leftarrow$ & $\begin{array}{l}-0.001 \\
+j 0.024\end{array}$ \\
\hline NDS & $\begin{array}{r}-0.042 \\
\pm \\
\pm 0.32\end{array}$ & $\begin{array}{l}+0.008 * \\
=10.30\end{array}$ & $\begin{array}{l}-0.003 \\
\leq j 0.076\end{array}$ & & $\begin{array}{l}-0.003 \\
=j 0.024\end{array}$ \\
\hline$P^{3}+N D S$ & $\begin{array}{r}-0.194 \\
\pm j 0.31\end{array}$ & $\begin{array}{l}-0.0008 \\
+j 0.30\end{array}$ & $\begin{array}{l}-0.003 \\
\pm j 0.076\end{array}$ & $\begin{array}{l}-0.12 \\
\pm j 0.016\end{array}$ & $\begin{array}{l}-0.003 \\
\pm j 0.024\end{array}$ \\
\hline$P^{*}+\mathrm{KDS}$ & $\begin{array}{r}-0.043 \\
+90.31\end{array}$ & $\begin{array}{l}-0.002 \\
=30.30\end{array}$ & $\begin{array}{l}-0.003 \\
\pm j 0.076\end{array}$ & $\begin{array}{l}-0.11 \\
\pm j 0.039\end{array}$ & $\begin{array}{l}-0.004 \\
=j 0.024\end{array}$ \\
\hline$P^{2}+\mathrm{NDS}$ & $\begin{array}{l}-0.044 \\
\pm j 0.31\end{array}$ & $\begin{array}{r}-0.004 \\
-\quad 0.30\end{array}$ & $\begin{array}{l}-0.003 \\
\pm j 0.075\end{array}$ & $\ldots$ & $\begin{array}{l}-0.003 \\
\pm j 0.027\end{array}$ \\
\hline
\end{tabular}

(注) 又力信号伎一A

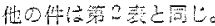

TRS 伝垟閶数

$$
=K_{\mathrm{TRS}} \frac{0.04 \mathrm{~S}}{1+0.04 \mathrm{~S}^{\prime}} \frac{0.02 \mathrm{~S}}{1+0.02 \mathrm{~S}}
$$

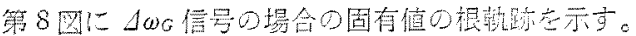
ここに示されたように，固有値の種頻により，利得に 対する固有值の苳化様相が县なり，古る根は安定方向 人，别の根估不安定方向に移動守るので，全ての根加 实定て古万制御䒺在邀定する必要がある。

第 4 裴は，利得 K $\mathrm{TRS}$ 在大きくした璂合の，各固有 値の動总示守ものである。ここに固有值の種別を表

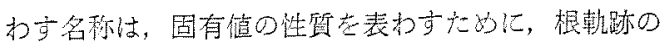
動きよりつけたあのである。

このような固有値の動き老考慮して, 全ての根が安

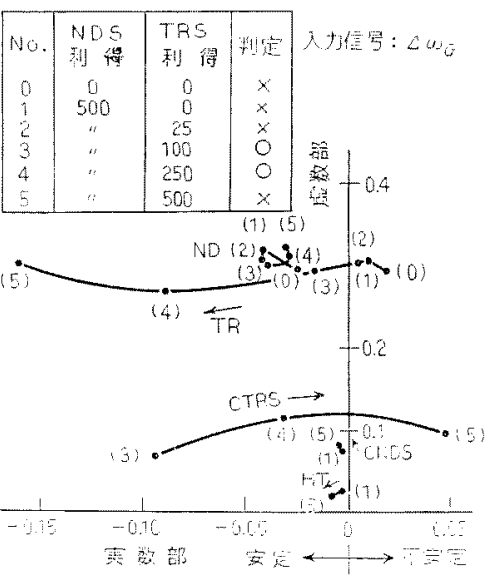

第 8 図 TRS の利得婆化に上万固有值の轨跡 Fig. 8. The loci of eigen-values where the gain value of TRS is increased.

第 4 表 利得を大きくしたときの各 固有值の動き

Table 4. Influence of the TRS over each eigenvalue with increasing the gain value of the TRS.

\begin{tabular}{|c|c|c|c|c|}
\hline 壾 号 & 固有做的盘別 & $\triangle P$ 入力 & $\Delta \omega_{G}$ 内力 & $\Delta \omega r \lambda 力$ \\
\hline$N D$ & 自己励酸心粗 & 0 & $\Delta(x)$ & $\Delta(x)$ \\
\hline TR & 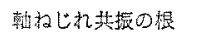 & 0 & 0 & 0 \\
\hline CNDS & NDS制湖菜による椹 & $\Delta$ & $\triangle$ & $\Delta$ \\
\hline CTRS & TRS 制御䒺による根 & $x$ & $x$ & $\triangle$ \\
\hline HT & ハンチングの根 & $\Delta(x)$ & $\Delta(0)$ & $\Delta(x)$ \\
\hline (注) & 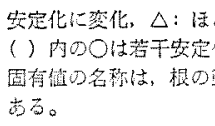 & 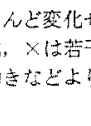 & in & 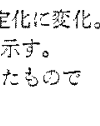 \\
\hline
\end{tabular}

第 5 表 生ての根が安定となる利得の筑四 Table 5. The proper values of the gain. value of the TRS which make every oscilla. tion to damp.

\begin{tabular}{|c|c|c|c|}
\hline 入力僐号の程列 & $\Delta P 入 力$ & $\Delta \omega_{C} \lambda 力$ & $\Delta \omega T$ 入力 \\
\hline 到得 $K_{\mathrm{TRS}}$ の範团 & $25 \sim 250$ & $40 \sim 350$ & $10 \sim 250$ \\
\hline
\end{tabular}

定上なる利得の筑围在求方第5表の上うになる。 即与, $\Delta P, \Delta \omega_{T}$ の最適利得驻 100 程虚， $\Delta \omega_{G}$ 入力 の場合は200 程振である。

なお，TRS の選定には，発電機の持っている他の

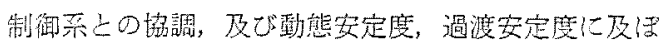
す影朁などを考慮する必要がある。

〈4・3〉軸ねじれ共振現象の抑制効果 モデル柔

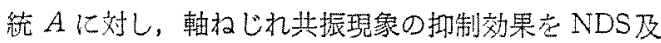
び TRSについて計算し，第9図の結果を得た。(a) 


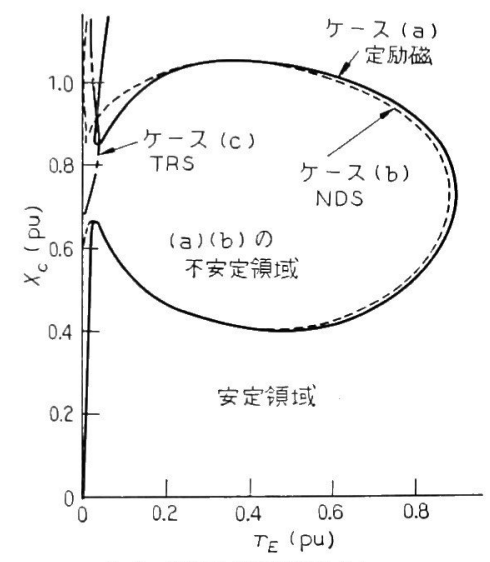

(a) 定励磁(抑制装圈なし)

(b) NDS(TRSなL)

(c) TRS (NDSなし)

第 9 図 モデル系統 $A$ における各抑制 装置の効果

Fig. 9. Stability borderlines for SSR in the model system with and without NDS and TRS.

は定励磁の場合，（b）はNDS（伝達関数は第 2 図之同 じ)でありの場合，（c）は TRS 有りの場合の安定判 別曲線である。TRS の入力信号は $\Delta \omega_{G}$ で伝達関数は (10)式に示すむのを使用した。

TRS 伝達関数

$$
=200 \frac{0.04 S}{1+0.04 S} \frac{0.02 S}{1+0.02 S}
$$

NDS 使用時の不安定領域は定励磁の場合之ほとん ど同じであるのに対し，TRS 使用時には不安定領域
がなくなっている。これは軸㸚じれ共振現象が有効電 力制御の支配を受け易いことを示しているあのと見ら れる。

軸ねじれ共振現象は，現象が拡大発散するのが問題 であるばかりでなく, 減衰が遅いこと屯軸疲学の面で 無視できないため，第 6 図 $X, Y$ で示す不安定領域に 非常に近接した 2 点を選んで, 直列コンデンサの短絡 (0.08 悡間)，再そう入を行ない，系統じょう乱発生 時の過渡軸トルク振動に対する効果をモデル系統 $B$ で 計算した。

第 10 図はケース X の場合で，タービン・発電機 間の軸共振周波数佰近く, タービン・発電機間のトル ク変動 $\left(T_{G T}\right)$ が大きくなっている。この場合には TRS による抑制効果は非常に大きいが，NDS による 抑制効果はほとんど期待できない。乙机に対し第11図 はケース $Y$ の場合で, 発電機・励磁機間の軸共振周 波数に近く, 発電機・励磁機間のトルク变動 $\left(T_{G E}\right)$ か 大きくなっている。ての場合には NDS の効果か認め られるが，逆に TRS の効果が小さくなっている。て れは，ここで検討したTRS が，発電機・励磁機間の 軸振動に対し，タービンの蒸気入力を抑制するという 間接的な形をとっているためと考えられる。

第 7 図に $P_{C}$ で示すような, 電気的エネルギー蓄皘 装置の制御により, 発電機の出力トルク変動を小さく すれば，このような現象に対しても，有効な抑制効果 を示すであるう。

$\langle 4 \cdot 4\rangle$ 具体化の構想 タービンの機械入力を高 速で制御することは，現用の調速機を対象に考える

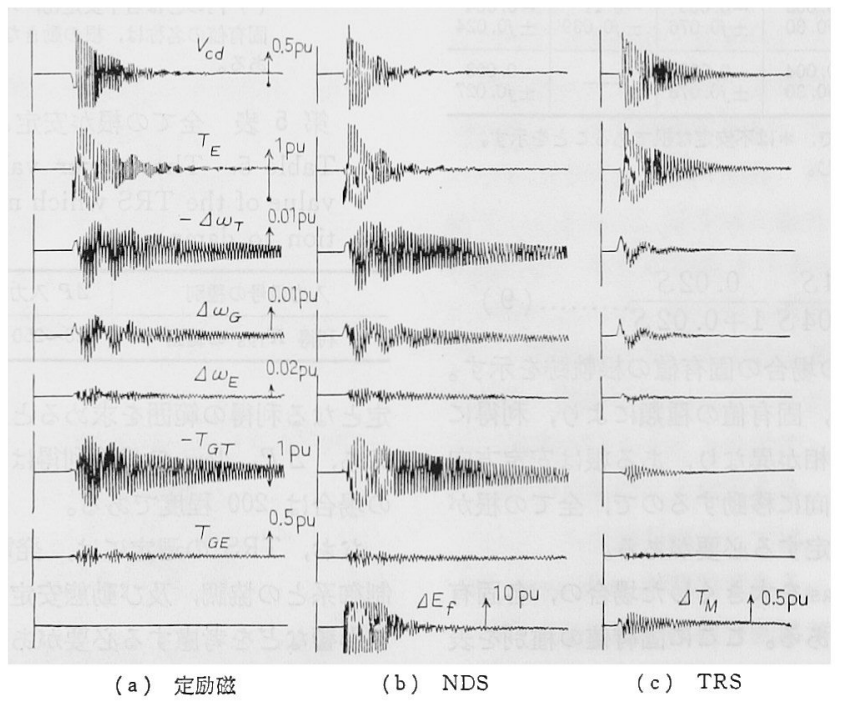

第 10 図過渡振動に対する NDS, TRS の効果 (10GVA ベース, 計算条件は第 5 図ヶース X)

Fig. 10. Transient oscillations in the model system (case $X$ in Fig. 5.) with and without NDS and TRS. 


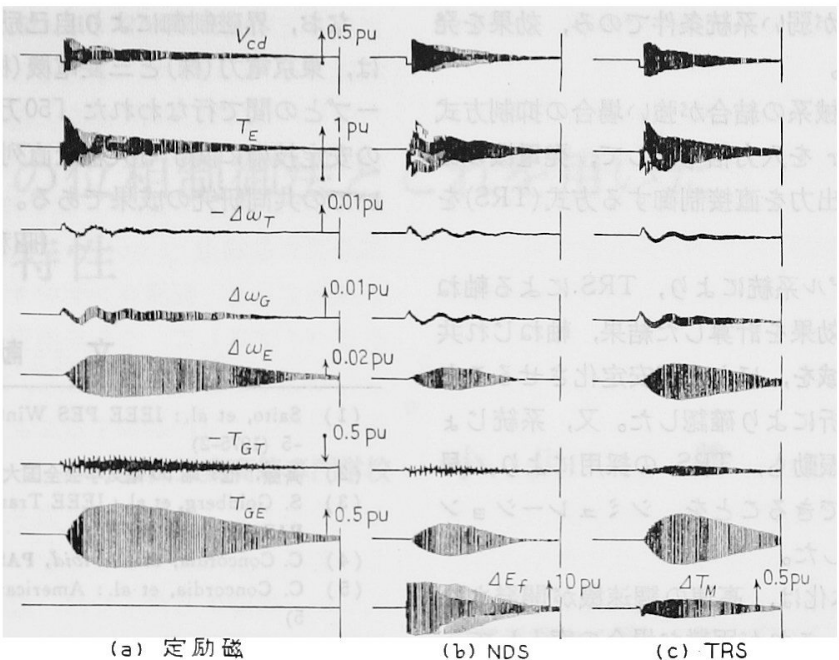

第 11 困 過渡振動に対する NDS, TRS の効果 (10GVA ベース, 計算条件は第 5 図ヶース Y)

Fig. 11. Transient oscillations in the model system (case Y in Fig. 5) with and without NDS and TRS.

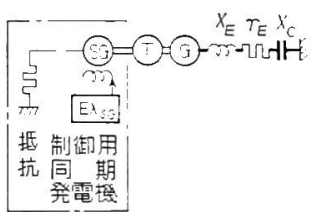

(a) 発電制御方式

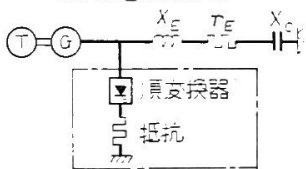

(c) 頁榙制御方式 I

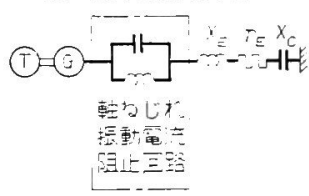

(e) 電流隄上方式

第 12 図各種軸称じれ共振現象抑制装置 の原理図

Fig. 12. The principle diagram of various kinds of TRS equipment.

と，その時間遅れ特性より考えて効果がない。

従って, 今後の技術革新により, 高速制御の調速機 制御装置が開発されれば，乙机を適用すれば良いが， これが困難な場合には，次のような高速制御が，比較 的容易汇実施できる方式として考えられる。

即ち，第 7 図に $\Delta T_{M}$ で示すものの具体化案につい て，その 1 例を第 12 図(a)に示す。これは, タービン (T) 亿直結して,小容量の制御用同期発電機 $(S G)$ を接 続し, その出力端に抵抗器を接続し, この SG の出力
電圧を，高速の界磁制御装置で制御する方式である。

又, 第 7 図に $P_{C}$ で示すむのについては, 第 12 図 (b) 〜 (d) K， その具体的な原理図を示す。(b)は, リアクトル・コンデンサ・バッテリ(蓄電池)をエネル ギー蓄積装置として利用し，（c）は変動分だけを抵抗 で消費するもの，(d)は直流連系がある場合に，それ を利用して，直流連系側の変換電力を高速に制御する 屯のである。

これらの抑制装置を，実際に開発するには技術的に 検討すべき点が多数あり, 又, 経済性も考虑の上, 適 当な方式を選定する必要があろう。又, 第 12 図(e) に示すような, 他の研究者より提案されている方式(5) との比較を行なう必要屯あるが, これらは別の機会に 検討するととにする。

\section{5. むすび}

直列コンデンサ補償系統では, 電気系の振動周波数 之機械系の振動周波数が近づくと, 非常に危倹である ことは, 1970 年アメリカにおける事故発生 ${ }^{(3)}$ 以来, クローズアップさ机て来た問題で, 種々の研究が行な われている(4) (10)。

本稿はこの軸ねじれ共振現象の抑制方式を研究した あので，次のような点を明らかにした。

（1）軸衫じれ共振現象を解析する方法を開発し， 既に報告されている論文 ${ }^{(4)}$ と一致する結果を得た。

(2) 同期機の界磁電圧制御 (NDS) ${ }^{(1)(2)}$ は, 電気 系の自己励磁現象に対しては，抑制効果を持つ。しか し,このNDSは, 軸ねじれ共振現象に対しては, 電 


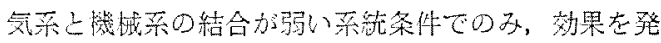
揮するととが判った。

（3）電気系之機械采の結合加強い埸合の抑制方式 としては， $P, \omega_{G}, \omega_{T}$ を入力信号として, 発電機の機 域入力, 又は, 電気出力を直接制御寸る万场(TRS) 䒓案した。

（4） $500 \mathrm{kV}$ モデル系統により，TRS、による軸稀 し机共振現象の制御效果を計算した結果，軸衫じれ共 振による不安定性領域を, ほとんど安定化させるとと ができることを，解析により確認した。又，系統じょ う乱任よる朝トルク振動も，TRSの採用により，早 く滅衰させるととがでることを、シミニレーション 計算結果で明らがした。

（5）TRSの具体化は，高速の調速機が開発され れば，容易であるが，てれが困難な場合の案として， 「発電制御」, 「負荷制御 $(1),(2)$, 「並列直流送電」 を提案した。しかし，こ机らの具体化には今後の研究 開発が必要である。

最㣪佂，本研究の解析手法の開発汇御協力頂いた福 井工業高等専門学校の守川䅭助教授比感謝する。
な考，界磁制御比上り自己励磁現象の抑制装䈯 ${ }^{(1)(2)}$ は, 東京電力 (㧣) と三菱電機 (株), 日新䨮機 (秼) グル

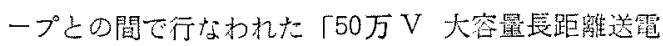
の安定技術に関する大容量直列コンデンサ方式」につ いての共同研筧の成果である。

(昭和 50 年 7 月 17 日受付)

\section{文献}

(1) Saito, et al.: IEEE PES Winter Meeting No. T 75, 180 $-5(1975-2)$

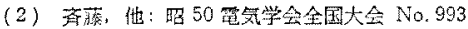

(3) S. Goldberg, et al. : IEEE Trans. Power Apparatus Syst. PAS-92, 1649 (1973)

(4) C. Concordia, et al.: ibid, PAS-92, 1688(1973)

(5) C. Concordia, et al.: American Power Conference (19735)

(6) R.A. Hedin, et al.: ibid (1973-5)

(7) L.A. Kilgore, et al.: ibid (1973-5)

(8) E.R. Taylor, et al. : CIGRE No. 21-29 (1974-8)

(9) S. Goldberg, et al.: IEEE PES Winter Meeting No. C73, 135-1 (1973-2)

(10) D. N. Walker, et al. : IEEE PES Winter Meeting No. T 75, 176-3 (1975-2)

(11) C. Concordia, et al.: AIEE Trans. Fower Apparatus Syst. PASm60, 116 (1941) 